УДК 82.09

М.А. Дерій

\title{
ТЕМА «ЗОЛОТОÏ ЛИХОМАНКИ» У ЗБІРЦІ ДЖЕКА ЛОНДОНА «ПІВНІЧНІ ОПОВІДАННЯ»
}

У струмку Бонза-Крік у районі річки Клондайк (Аляска) 16 серпня 1896 року групою з чотирьох старателів відкрито великі поклади золота, що стало початком явища під назвою «золота лихоманка», а слово «Клондайк» стало синонімом джерела величезних благ, на які сподівалися тисячі людей. Насправді Клондайк (англ. Klondike або Clondike) - регіон, що розташований на території Юкон, на північному заході Канади, на схід від кордону з Аляскою. Клондайк простягається уздовж невеликої річки з однойменною назвою, що впадає в річку Юкон, яка розташована на схід від міста Доусон-Сіті. Саме тут розпочала свою історію «золота лихоманка», яка захопила більшість країн світу та принесла багато страждань для спраглих до кращого життя та легкого збагачення людей.

Пошук незвіданого щастя, безмежних покладів золота, або просто «золота лихоманка» $є$ однією з провідних тем збірки «Північні оповідання» Джека Лондона. «Північні оповідання» Джека Лондона - умовна назва ранніх творів письменника, з якими він увійшов у світову літературу. Збірку об'єднує система мотивів, пов'язаних із темою «золотої лихоманки». Бінарні мотиви життя і смерті, дружби і зради, боротьби і безсилля духу визначають зміст, композицію і образну систему творів митця.

Тема неорганізованого масового видобування золота та відкриття нових родовищ у другій половині XIX - на початку XX ст. у різних частинах світу дуже важлива, тому що саме теми «золотої лихоманки» суттєво переформували світ, уможливили масштабне заселення пустих континентів, обумовили створення нових міст, транспортних i торговельних шляхів, розвинули світову фінансову систему, сприяли значному підсиленню Сполучених Штатів Америки, що призвело до вагомих геополітичних змін та формування картини світу.

(C) М.А. Дерій, 2019

https://doi.org/10.34142/2312-1076.2019.3.93.04 
44 Наукові записки ХНПУ ім. Г.С. Сковороди. Літературознавство, 2019, вип. 3(93)

У західній науковій літературі мотиви «золотої лихоманки» (The Gold Rush) представлені досить повно й різнопланово: Ralph Andrist «The Gold Rush» (2015); Keir Reeves, Lionel Frost and Charles Fahey «Integrating the Historiography of the Nineteenth-Century Gold Rushes» (2010); Franç ois Micheloud, «The Crime of 1873: Gold Inflation this time» (2004); Michael North «Das Geld und seine Geschichte» (1994); Pierre Berton «Klondike: The Last Great Gold Rush, 1896-1899, Random House of Canada» (2001) та інші.

У літературознавстві тему «золотої лихоманки» в творчості Джека Лондона вивчали такі дослідники: М. Kuzmicheva «Narrative Features of 12 Klondike Stories by Jack London. Semiodiscursive and Textual Approach» [14], Y. Koptevich «The comporative characteristics of the images in Jack London's novel «White Fang» [12], Kreidler, L. Michele «Jack London's «To build a fire» [13], Савченко 3.В. «Північні» оповідання Джека Лондона з погляду індивідуальної авторської манери» [10] та інші. Автори літературно-критичних досліджень поціновують мовну майстерність Джека Лондона, називаючи серед домінант ідіостилю письменника розкутість форми, поглиблену метафоричність, віддалену асоціативність поняття «золотої лихоманки».

Мета нашого дослідження - схарактеризувати вияви теми «золотої лихоманки» у збірці «Північні оповідання» Джека Лондона. Мета вимагає постановки наступних завдань:

- з'ясувати особливості втілення теми «золотої лихоманки»у спадщині письменника;

- простежити особливості зміни характерів у людей в екстремальних умовах;

- з'ясувати основні мотиви збірки «Північні оповідання» Джека Лондона.

Головне, на що ми звертаємо увагу вивчаючи тему «золотої лихоманки», - це поєднання та водночас протистояння людини і природи у складних екстремальних умовах. Джек Лондон з детальною точністю, яка взагалі була притаманна його творчості, описав побут золотошукачів, дії та кожний крок. У його творах людина сильна духом могла зробити неможливі речі: «...він звільнив особистість із 
твердих лещат біологічної залежності: навіть у найтяжчих обставинах герої “північної одіссеї” не безпомічні - фізичне знесилення перемагається ними за рахунок твердості духу та моральної стійкості» $[10$, c. 3$]$.

Пишучи свої «Північні оповідання», Джек Лондон спирався на свій практичний досвід, у якому перемішались жорстокість «білої тиші», з одного боку, і романтика боротьби за життя, а ще більше - за збереження морального обличчя людини та доброти в ситуаціях, коли вистояти могла лише насправді сильна духом особистість, з іншого.

Однією із суттєвих рис, що пронизує всі твори Джека Лондона про Північ, є мотив пригоди, він об'єднує людей різних професій та національностей, несе у собі небезпеку та невизначеність 3 одного боку та романтизм з іншого, адже в таких ситуаціях людина $є$ частиною природи і їі почуття особливо загострюються. Марія Кузьмичева у своїй роботі «Narrative Features of 12 Klondike Stories by Jack London. Semiodiscursive and Textual Approach» має схожу думку: «There are a great number of people of different professions, characters, ages, nationalities and religions. The content of the stories is always different; some of them are about human heroism, others deal with human cruelty. They all speak about adventures, about the fight with Nature, the passion for gold, about the will to live and faith in man» [14, c. 34-35].

Тема «золотої лихоманки» порушує важливі проблеми варварського розграбування природи для задоволення спраги наживи. Джек Лондон відтворює прекрасні картини природи й водночас страшні наслідки діяльності людини на Алясці.

Одним із найвідоміших творів, що увійшов до збірки «Північні оповідання», є коротке оповідання «Жага до життя» (1905). Можна сміливо стверджувати, що дане оповідання містить значну частину автобіографічності, адже грунтується на реальних подіях, коли письменник здобував великий життєвий і письменницький досвід, плаваючи матросом на шхунах та підкорюючи Північ під час «золотої лихоманки». Життя дало йому безліч яскравих вражень, які він відобразив у своїх творах. Історично-правдивий контекст твору підтверджується географічною деталізацією шляху його героя - від 
Великого Медвежого озера до гирла річки Коппермайн, що впадає у Північний Льодовитий океан.

Типова картина «золотої лихоманки» представлена в оповіданні «Жага до життя». Двоє друзів, які подорожують у пошуках золота, не розрахували сили на дорогу додому. Немає провізії, немає патронів, немає елементарних психічних і фізичних ресурсів - всі дії відбуваються автоматично, немов у тумані. Герой, під час переходу через струмок, оступається і пошкоджує ногу. Товариш на ім'я Білл без найменших роздумів кидає його і йде, навіть не озирнувшись: «Bill staggered on through the milky water. He did not look around. The man watched him go, and though his face was expressionless as ever, his eyes were like the eyes of a wounded deer» [12].

Головною ідеєю оповідання $\epsilon$ думка про те, що боротьба людини 3 природою за право існування нещадна, незважаючи на те, що людина озброєна ще й розумом. Джек Лондон стверджує, що природа не має жалю й поблажливості до будь-кого. 3 точки зору природного виживання Білл вважав себе правим, позбавляючись від баласту у вигляді пораненого приятеля. Але водночас, як вважає митець, важливіше залишатися людиною до кінця. У цьому оповіданні виявляється світогляд Джека Лондона, його погляди на життя. Письменник у своїх творах про Північ зображував картини природи, прекрасну Аляску, корінних жителів, людей, захоплених «золотою лихоманкою» та власні враження від побаченого. Проте головна тема «Північних оповідань» - боротьба не за золото, а за людину. Закони природи у Джека Лондона суворі, але справедливі. Біда приходить тоді, коли людина відступає від цих законів, стає жадібною, прагне лише наживи. Джек Лондон прославляє сильних духом, сміливих людей, які знають, чого хочуть. Це можна простежити з початку оповідання, адже епіграф до твору звучить як його головна ідея: «This out of all will remain. They have lived and have tossed, so much of the game will be gain, though the gold of the dice has been lost» [12].

Письменник неодноразово звертався до техніки натуралізму та імпресіонізму, створюючи піднесено-романтичні картини перемоги виняткової особистості над стихією. Коли ж виникала потреба 
показати складність взаємовідносин між людиною і середовищем, прозаїк виступав переконаним реалістом, щоправда, за спостереженням О. Звєрєва, поєднуючи бездоганну правдоподібність кожної подробиці з поетичною фантазією і ліричними відступами, що перебивали стрімке розгортання інтриги, надаючи оповіді епічного розмаху й філософської глибини [6, с. 32].

Центральною темою циклу «Північних оповідань» Джека Лондона стала тема випробувань. Письменник послідовно відтворював ситуації, у яких особистість, залишаючись наодинці з небезпекою, отримувала можливість перевірити власні сили в тяжкій боротьбі 3 обставинами, що загрожують १iї існуванню. На Півночі потенціал, закладений в індивіді природою, виявлявся набагато повніше, i, вперше по-справжньому осягаючи зміст давно відомих, звичних понять, людина неначе заново відкривала для себе першоматерію буття, відкидаючи все штучне й другорядне. У підсумку до неї приходило розуміння високого змісту таких етичних категорій, як відповідальність, братерство, мужність, воля, честь, - розуміння не абстрактне, а пропущене крізь власний життєвий досвід [10, с. 310]. Залежно від особливостей оприявлення наратором тих чи інших подій, можна говорити про бінарність теми «золотої лихоманки» у творах Джека Лондона. 3 одного боку, мотив «золотої лихоманки» має негативний характер, є синонімом жадоби, жорстокості, нелюдських умов існування, незаконного збагачення тощо. 3 іншого боку, цей мотив можна розглядати позитивно, адже в самому терміні присутнє слово «золото», що може означати шлях до кращого життя, який шукали золотошукачі.

Зосереджуючи увагу лише на головному почутті, що у хвилини смертельної небезпеки робить непотрібним усе інше, Джек Лондон іноді відкидав тонкий психологізм, багатство відтінків і півтонів, звертаючись до стрімкої реалістичної оповіді, деякі картини його творів підчас вражали відвертістю натуралістичного стилю: «In the late afternoon he came upon scattered bones where the wolves had made a kill. The bones had been a caribou calf an hour before, squawking and running and very much alive. He contemplated the bones, clean-picked 
and polished, pink with the cell-life in them which had not yet died. Could it possibly be that he might be that ere the day was done! Such was life, eh? But he did not moralize long. He was squatting in the moss, a bone in his mouth, sucking at the shreds of life that still dyed it faintly pink. The sweet meaty taste, thin and elusive almost as a memory, maddened him. He closed his jaws on the bones and crunched. Sometimes it was the bone that broke, sometimes his teeth. Then he crushed the bones between rocks, pounded them to a pulp, and swallowed them. He pounded his fingers, too, in his haste, and yet found a moment in which to feel surprise at the fact that his fingers did not hurt much when caught under the descending rock» [12].

Однак письменник ані на мить не забував про велич розпачливої битви людини за право на життя, оспівував високі моральні принципи й мужність залишатися особистістю навіть у хвилини повної безвиході, що вводило оповідання «північного» циклу в контекст неоромантичної естетики.

Відтворюючи реалії повсякденного життя золотошукачів, Джек Лондон, звичайно ж, не міг уникнути натуралістичної деталізації. Але запропоноване письменником тлумачення людини рішуче протистояло провідним концепціям натуралістів. Зокрема, він звільнив образи персонажів від біологічної залежності: навіть у найтяжчих обставинах герої «північної одіссеї» не безпомічні - фізичне знесилення вони долають за рахунок твердої позиції та моральної стійкості. Персонажі, яким Джек Лондон відверто симпатизує, утілюють романтичний ідеал автора: вони - сильні особистості, що сповідують закони братерства і справедливості [10, с. 310].

Екстремальні умови найкраще виявляють характери персонажів. Одні, як герої багатьох оповідань Джека Лондона, наприклад, Мелмют Кід, незважаючи ні на що, залишаються людьми, вони завжди готові допомогти ближньому, старанно навчаються розпізнавати істинне й фальшиве, і реалізовуються як особистості у тяжкій i наполегливій праці, яка рано чи пізно дає плоди. Водночас інші персонажі живуть упівсили, лінуються, намагаючись вижити за рахунок інших, таких людей жорстока Північ нерідко перетворювала 
на звіроподібних нелюдів, ладних перегризти одне одному горло за грудочку цукру.

Отже, тема «золотої лихоманки», яку порушує в своєму циклі «Північні оповідання» Джек Лондон, дуже важлива, тому що саме «золоті лихоманки» суттєво переформували світ, спричинили масштабне заселення пустих континентів, обумовили створення нових міст, відкриття транспортних і торговельних шляхів. Водночас звернення до теми «золотої лихоманки» допомогло виявити соціальні й моральні проблеми суспільства. Центральною темою «Північних оповідань» Джека Лондона стала тема випробувань: письменник послідовно створював ситуації, у яких особистість, залишаючись наодинці з небезпекою, отримувала можливість перевірити власні сили в тяжкій боротьбі з обставинами, що загрожують самому їі існуванню.

Більшості «Північних оповідань» притаманна пригодницька складова, що приваблювало читачів. Твори Джека Лондона про «золоту лихоманку» дали поштовх до роздумів для наступних письменників. Джек Лондон - багатогранний та цікавий письменник, дослідженням його творчості займаються багато науковців, критиків, письменників в Україні та світі. Такий напрям дослідження творчості Джека Лондона вважається перспективним, адже допомагає краще пізнати реалії минулого та отримати уявлення про тогочасну картину світу.

\section{Література}

1. Аникин А. В. Золото. М.: Международные отношения, 1984. 320 с.

2. Быков В. М. По следам Джека Лондона. М.: МГУ, 1996. 238 с.

3. Быков В. М. Джек Лондон. М.: МГУ, 1964. 253 с.

4. Денисова Т. Н. Джек Лондон. Життя і творчість. К.: Дніпро, 1978. 125 с.

5. Дубровська А.С. Символ золота: інфернальний смисл (за романом В. Винниченка «Поклади золота»). Вісник Харківського національного університету. Сер.: Філологічні науки № 873. Вип. 58. Харків, 2009. С. $118-122$.

6. Зверев А. М. Джек Лондон. М.: Знание, 1975. 64 с.

7. Корунець I. В. Джек Лондон. К.: Знання, 1976. 48 с.

8. Літературознавчий словник-довідник. К.: Видавничий центр «Академія», $1997.752 \mathrm{c.}$

9. Марфунин А. С. История золота. М.: Наука, 1987. 248 с. 
10. Савченко 3.В. «Північні» оповідання Джека Лондона з погляду індивідуальної авторської манери. Наукові записки Ніжинського держ. ун-тету ім. М. Гоголя. Сер.: Філологічні науки. Ніжин, 2013. Кн. 1. С. $308-311$.

11. Foner, Ph. American rebel. New York, 1947. 237 p.

12. Koptevich Y. The comporative characteristics of the images in Jack London's novel «White Fang». Сборник статей и тезисов IX Междунар. науч. практ. конф., Минск, 25 ноября 2015 г. В 6 частях. Часть 5. Минск: БГУ, 2015. С. $58-64$.

13. Kreidler Michele L. Jack London's «To build a fire». Literary Contexts in Short Stories. 2009. P. 308-311.

14. Kuzmicheva M. Narrative Features of 12 Klondike Stories by Jack London. Semiodiscursive and Textual Approach. Tesi Doctoral UPF. Departament de Traducció i Ciències de Llenguatge. 2013. 546 p.

15. London, Jack. Love of life. URL: http://london.sonoma.edu/ Writings/ LoveLife/life.html.

16. North Michael. Das Geld und seine Geschichte. München: C.H. Beck, 1994. S. 121.

17. Ralph K. Andrist. The Gold Rush. New Word City, 2015. 145 p.

\section{References}

1. Anikin, A.V. Zoloto. Moskva: Mezhdunarodnye otnosheniya, 1984. $320 \mathrm{~s}$.

2. Bykov, V. M. Po sledam Dzheka Londona. Moskva: MGU, 1996. $238 \mathrm{~s}$.

3. Bykov, V. M. Dzhek London. Moskva: MGU, 1964. 253 s.

4. Denisova, T. N. Dzhek London. Zhittya i tvorchist. Kyiv: Dnipro, 1978. $125 \mathrm{~s}$.

5. Dubrovska, A.S. Simvol zolota: infernalniy smisl (za romanom V. Vinnichenka «Pokladi zolota»)/Visnik Kharkivskogo natsionalnogo universitetu. Ser.: Filologichni nauki № 873. Vip. 58. 2009. S. 118-122.

6. Zverev, A. M. Dzhek London. Moskva: Znanie, 1975. 64 s.

7. Korunets, I. V. Dzhek London. Kyiv: Znannya, 1976. 48 s.

8. Literaturoznavchiy slovnik-dovidnik. Kyiv: Vidavnichiy tsentr «Akademiya», 1997. $752 \mathrm{~s}$.

9. Marfunin, A. S. Istoriya zolota. Moskva: Nauka, 1987. $248 \mathrm{s.}$

10. Savchenko, Z.V. «Pivnichni» opovidannya Dzheka Londona z poglyadu individualnoï avtorskoï maneri. Naukovi zapiski Nizhinskogo derzh. un-tetu im. M. Gogolya. Ser.: Filologichni nauki. 2013. Kn. 1. S. 308-311.

11. Foner, Ph. American rebel. New York, 1947. 237 p.

12. Koptevich, Y. The comporative characteristics of the images in Jack London's novel «White Fang». Cbornik statey i tezisov IX Mezhdunar. nauch. 
prakt. konf., Minsk, 25 noyabrya 2015 g./ Redkol.: N.N. Nizhneva (otv. redaktor) [i dr.]. V. 6 chastyakh. Chast' 5. Minsk.: BGU, 2015. P. 58-64.

13. Kreidler, Michele L. Jack London's «To build a fire». Literary Contexts in Short Stories. 2009. P. 308-311.

14. Kuzmicheva M. Narrative Features of 12 Klondike Stories by Jack London. Semiodiscursive and Textual Approach. Tesi Doctoral UPF. Departament de Traducció i Ciències de Llenguatge. 2013. 546 p.

15. London, Jack. Love of life. URL: http://london.sonoma.edu/ Writings/ LoveLife/life.html.

16. North, Michael. Das Geld und seine Geschichte. München: C.H. Beck, 1994. S. 121.

17. Ralph, K. Andrist. The Gold Rush. New Word City, 2015. 145 p.

\section{Анотація \\ М.А. Дерій. Тема «золотої лихоманки» у збірці Джека Лондона «Північні оповідання»}

«Північні оповідання» Джека Лондона - умовна назва ранніх творів письменника, з якими він увійшов у світову літературу. Збірку об'єднує система мотивів, пов'язаних із темою «золотої лихоманки». Тема «золотої лихоманки» порушує важливі проблеми варварського розграбування природи для задоволення спраги наживи. Джек Лондон відтворив прекрасні картини природи й водночас жахливі наслідки діяльності людини на Алясці.

Центральною темою циклу «Північних оповідань» Джека Лондона стала тема випробувань. Письменник послідовно відтворював ситуації, у яких особистість, залишаючись наодинці з небезпекою, отримувала можливість перевірити власні сили в тяжкій боротьбі з обставинами, що загрожують іiі існуванню. Відтворюючи реалії повсякденного життя золотошукачів, Джек Лондон, звичайно ж, не міг уникнути натуралістичної деталізації. Але запропоноване письменником тлумачення людини рішуче протистояло провідним концепціям натуралістів. Зокрема, він звільнив образи персонажів від біологічної залежності: навіть у найтяжчих обставинах герої «північної одіссеї» не безпомічні - фізичне знесилення вони долають за рахунок твердої позиції та моральної стійкості. Персонажі, яким Джек Лондон відверто симпатизує, утілюють романтичний ідеал автора: вони - сильні особистості, що сповідують закони братерства і справедливості.

Одною з головних рис, що пронизує всі твори Джека Лондона про Північ, є мотив пригоди, він об'єднує людей різних професій та національностей, несе в собі небезпеку та невизначеність з одного боку та романтизм 3 іншого. Пишучи свої «Північні оповідання», Джек Лондон спирався на свій практичний досвід, в яких перемішались жорстокість «білої тиші», 3 
52 Наукові записки ХНПУ ім. Г.С. Сковороди. Літературознавство, 2019, вип. 3(93)

одного боку, і романтика боротьби за життя, а ще більше - за збереження морального обличчя людини та доброти в ситуаціях, коли вистояти могла лише насправді сильна духом особистість, з іншого.

Ключові слова: Джек Лондон, «золота лихоманка», образ, символ, мотив.

\section{Аннотация \\ М.А Дерий. Тема «золотой лихорадки» в сборнике Джека Лондона «Северные рассказы»}

«Северные рассказы» Джека Лондона - условное название ранних произведений писателя, с которыми он вошел в мировую литературу. Сборник объединяет система мотивов, связанных с темой «золотой лихорадки». Тема «золотой лихорадки» поднимает важные проблемы варварского разграбления природы для удовлетворения жажды наживы. Джек Лондон воссоздал прекрасные картины природы и одновременно ужасные последствия деятельности человека на Аляске.

Центральной темой цикла «Северных рассказов» Джека Лондона стала тема испытаний. Писатель последовательно воспроизводил ситуации, в которых личность, оставаясь наедине с опасностью, получала возможность проверить собственные силы в тяжелой борьбе с обстоятельствами, которые угрожают ее существованию. Воспроизводя реалии повседневной жизни золотоискателей, Джек Лондон, конечно же, не мог избежать натуралистической детализации. Но предложенное писателем толкование человека решительно противостояло ведущим концепциям натуралистов. В частности, он освободил образы персонажей от биологической зависимости: даже в самых тяжелых обстоятельствах герои «северной одиссеи» не беспомощны - физическое изнеможение они преодолевают за счет твердой позиции и моральной стойкости. Персонажи, которым Джек Лондон откровенно симпатизирует, воплощают романтический идеал автора: они - сильные личности, исповедующих законы братства и справедливости.

Одной из главных черт, пронизывающих все произведения Джека Лондона о Севере, является мотив приключения, он объединяет людей разных профессий и национальностей, несет в себе опасность и неопределенность с одной стороны и романтизм с другой. Джек Лондон писал свои «Северные рассказы» опираясь на свой практический опыт, в которых перемешались жестокость «белой тишины», с одной стороны, и романтика борьбы за жизнь, а еще больше - за сохранение морального облика человека и доброты в ситуациях, когда выстоять могла только на самом деле сильная духом личность, с другой.

Ключевые слова: Джек Лондон, «золотая лихорадка», образ, символ, мотив. 


\section{Summary}

\section{M.A. Deri. The Gold Rush Theme in Jack London's Northern Stories}

Jack London's «Northern Stories» is the conventional name of the early writer's works, with which he entered the world literature. The collection is composed of a system of motifs related to the theme of «gold rush». The theme of «gold rush» raises serious problems for barbaric looting of nature to satisfy greed. Jack London reproduced beautiful pictures of nature and at the same time the terrible consequences of human activity in Alaska.

The testing theme was the central theme in Jack London's «Northern Stories». The writer consistently reproduced situations in which a person, remaining alone with danger, was given the opportunity to test their own forces in a difficult struggle against circumstances threatening its existence. Reproducing the realities of everyday life of goldsmiths, Jack London, of course, could not escape the naturalistic detail. But the writer's proposed interpretation of man strongly opposed the leading concepts of naturalists. In particular, he freed characters from biological dependence: even under the worst circumstances, the heroes of the «Northern Stories» are not helpless - they overcome physical deterioration due to solid positions and moral stability. Characters that Jack London frankly sympathizes with embody the romantic ideal of the author: they are strong personalities who adhere to the laws of brotherhood and justice.

One of the main features that permeates all Jack London's writings about the North is the adventure motif, it unites people of different professions and nationalities, includs the danger, uncertainty and romanticism. Jack London wrote his «Northern Stories» based on his practical experience, in which the cruelty of «white silence», on the one hand, and the romance of the struggle for life, on the other hand, and, moreover, the preservation of the moral person's face and kindness in situations where could stand only a person who has a strong spirit.

Key words: Jack London, «golden rush», image, symbol, motif.

\section{Інформація про автора}

Дерій Марина Анатоліївна - здобувач ступеня доктора філософії кафедри світової літератури Полтавського національного педагогічного університету імені В.Г. Короленка; вул. Остроградського, 2, м. Полтава, Полтавська область, 36000, Україна; e-mail: nestmarinka2010@gmail.com; https:// orcid.org/0000-0002-7523-3699 